\title{
NARRADORES Y REFLEXIVIDAD EN EL DOCUMENTAL POLÍTICO DEL TARDOFRANQUISMO Y LATRANSICIÓN DEMOCRÁTICA (1967-1977)
}

\author{
NARRATORS AND REFLEXIVENESS IN THE POLITICAL DOCUMENTARY CINEMA \\ OF THE PERIOD BETWEEN LATE FRANCOISM AND THE DEMOCRATIC TRANSITION
}

(1967-1977)

\author{
Jorge NIETO FERRANDO \\ Universitat de Lleida \\ nietojordi@filcat.udl.cat
}

Resumen: En el tardofranquismo y la Transición democrática surge un cine documental que busca contrainformar, estimular la toma de conciencia respecto a ciertos problemas sociales e incluso contribuir al cambio social y político. Este cine se caracteriza por el enfrentamiento a los discursos informativos audiovisuales de la dictadura, tanto en lo referente a los temas que aborda como, sobre todo, a la manera de tratarlos. Este artículo analiza dos de las estrategias empleadas para ello: la proliferación de subnarradores y la diversidad de actitudes de estos frente a lo narrado.

Palabras clave: Cine documental. Narradores. Ironía. Parodia. Sinécdoque.

Abstract: A type of documentary film arose during the period between late Francoism and the democratic transition that sought to provide alternative information, stimulate awareness about certain social problems and even contribute to social and political change. This type of cinema is characterized by a confrontation with the audiovisual informative discourses of the dictatorship, both in regard to the issues addressed and, above all, about how they were treated. This article analyses two of the strategies employed to do this: the proliferation of sub-narrators and the variety of these narrators' attitudes to what was being narrated.

Key Words: Documentary cinema. Narrators. Irony. Parody. Synecdoche. 


\section{INTRODUCCIÓN}

En los últimos años del franquismo convergen dos fenómenos importantes en el ámbito cinematográfico. En primer lugar, eclosiona un cine fuera de las instituciones cinematográficas - ya sea por propia elección o por la imposibilidad de permanecer dentro de estas debido a la censura-, más allá del amateurismo, donde confluyen prácticas fílmicas que van desde la experimentación o la ficción hasta el documental militante. En ocasiones resulta difícil establecer con claridad las fronteras entre unas y otras, dado que la ruptura con las maneras convencionales de narrar y representar es planteada muchas veces como una forma de lucha e incluso militancia. En segundo lugar, repunta el documental, en gran medida surgido en el ámbito del cine independiente, caracterizado por abordar el presente y el pasado desde posiciones críticas con la dictadura franquista e incluso con los derroteros que seguirá la Transición a la democracia; un documental, además, que deja atrás toda estrategia posibilista de negociación con la censura.

El documental, y en concreto el que persigue como objetivo la contrainformación, la concienciación del espectador respecto a algún problema, la toma de partido político e incluso el cambio social, ha suscitado numerosas aproximaciones, sobre todo desde la crítica, la crónica o con la intención de establecer catálogos o nóminas de directores y películas (Antolín, 1979; Viota, 1982; Romaguera y Soler, 2006). Pero es a partir de mediados de los años noventa cuando la descripción y la información dejan paso a la interpretación y el análisis. Así puede apreciarse en los trabajos de Llinás, Pérez Perucha, Linares o Hernández y Pérez en Historia del cortometraje español (1996), o de Riambau, Larraz, Torreiro y Selva en Imagen, memoria y fascinación. Notas sobre el documental en España (2001). Con todo, destacan especialmente las publicaciones de Arnau (2006), García-Merás (2007) o Berzosa (2009), a las que hay que añadir las dedicadas a la producción de ciertos directores reconocidos por dedicar parte de su filmografía a este cine, como Antonio Artero (Hernández y Pérez, 1998), Pere Portabella (Expósito, 2001; Fanés, 2008) o Llorenç Soler (Francés, 2012).

A nuestro juicio, la relevancia de este cine reside en tres razones. En primer lugar, $y$ aunque pueda parecer una perogrullada, por el hecho de realizarse. Es común considerar que el documental implica un pacto de veracidad con el espectador sobre la base de la asunción de cierta correspondencia, de alguna manera susceptible de ser corroborada la mayor parte de las veces a través de otros textos sobre el mismo aspecto de la realidad-, entre el contenido de las películas y la realidad. Por este motivo, el documental, y en general los discursos audiovisuales de carácter informativo o referencial, fueron atados en corto por las instituciones cinematográficas franquistas. El mero hecho de realizar 
documentales aprovechando los resquicios de dichas instituciones o directamente fuera de ellas constituyó un acto de oposición a la dictadura.

En segundo lugar, es importante por los temas que aborda: la pobreza y la miseria; la migración del campo a la ciudad y el crecimiento desordenado de los barrios periféricos en las grandes urbes; la situación de los presos políticos y de las minorías y los grupos sociales marginados; la lucha obrera y estudiantil por los derechos sociales, la libertad y la democracia; o la represión ejercida por el Estado y sus reminiscencias tras la muerte de Franco. Es evidente que el tratamiento de dichos temas podía ser problemático en el tardofranquismo y la Transición, y sin duda estaban en gran medida ausentes en el No-Do y en los informativos televisivos. Las propias características de los noticiarios cinematográficos - con algunas excepciones-, como han señalado Tranche y SánchezBiosca, impedían su aparición en ellos, a lo que hay que añadir "la ausencia de análisis, de una mirada crítica que ofreciera al espectador una explicación de los hechos mostrados, de sus causas, el contexto o sus implicaciones. En suma, un mayor compromiso con la información" (2001: 86).

Con todo, y en tercer lugar, los documentales políticos, contrainformativos o militantes no se reducen a mostrar aspectos de una realidad diferente a la expuesta por el No-Do —el qué-, sino que también se enfrentan a las estrategias narrativas y representativas empleadas para ello — el cómo-. Esta cuestión surge una y otra vez en la abundante reflexión crítica que acompaña a las películas — véanse, por ejemplo, VV.AA. (1977) o Martí Rom (1978) —, y es especialmente apreciable en los recursos empleados para romper con el tipo de subnarrador en over del noticiario y con la relación ilustrativa y redundante que la imagen guarda respecto a la historia que este narra.

El objetivo del presente artículo es analizar este último punto. Para ello ha sido seleccionado el siguiente corpus de películas representativas:

\begin{tabular}{|l|l|l|}
\hline Año & Título & Tema \\
\hline \multirow{1}{*}{1967} & Distància 200 MTS (Jordi Bayona) & Desigualdades sociales \\
\cline { 2 - 3 } & 52 domingos (Llorenç Soler) & Pobreza y aspiraciones sociales \\
\hline \multirow{1}{*}{1968} & Urani 235 (Jordi Bayona) & Guerra de Vietnam \\
\cline { 2 - 3 } & No se admite personal (Antonio Lucchetti) & Precariedad laboral \\
\cline { 2 - 3 } & $\begin{array}{l}\text { Spagna 68 (El hoy es malo, pero el mañana es } \\
\text { mío) (Helena Lumbreras y Llorenç Soler) }\end{array}$ & Lucha contra el franquismo \\
\cline { 2 - 3 } & D'un temps d'un pais. Raimon (Llorenç Soler) & Reivindicación cultural \\
\hline 1969 & Monegros (Antonio Artero) & Situación del campo \\
\cline { 2 - 3 } & Distància, de 0 a infinit (Jordi Bayona) & Desigualdades sociales \\
\cline { 2 - 3 } & Aidez l'Espagne (Pere Portabella) & Guerra Civil y sus consecuencias \\
\cline { 2 - 3 } & Largo viaje hacia la ira (Llorenç Soler) & Inmigración en las grandes ciudades \\
\hline
\end{tabular}




\section{JORGE NIETO FERRANDO}

\begin{tabular}{|c|c|c|}
\hline Año & Título & Tema \\
\hline \multirow[t]{4}{*}{1970} & El cuarto poder (Helena Lumbreras) & $\begin{array}{l}\text { Libertad de información, de expresión y } \\
\text { medios de comunicación }\end{array}$ \\
\hline & \begin{tabular}{|l} 
Poetes catalans (Pere Portabella) \\
\end{tabular} & Reivindicación cultural \\
\hline & El Altoparlante (Llorenç Soler) & Discurso franquista \\
\hline & Noticiario RNA (Llorenç Soler) & No-Do \\
\hline \multirow[t]{4}{*}{1971} & Un lloc per dormir (Jordi Bayona) & $\begin{array}{l}\text { Inmigración. Barrios periféricos de las } \\
\text { grandes ciudades }\end{array}$ \\
\hline & \begin{tabular}{|lcc} 
Montserrat, assemblea d'intel.lectuals \\
(Muntanya) (Comissió de Cinema de \\
Barcelona)
\end{tabular} & Presos políticos y actos de protesta \\
\hline & $\begin{array}{l}\text { Canciones para después de una guerra (Basilio } \\
\text { Martín Patino) }\end{array}$ & Posguerra \\
\hline & $\begin{array}{l}\text { Mitin en Montreuil (Pere Portabella, Carles } \\
\text { Durán, Manuel Esteban, Brigitte Dornés y el } \\
\text { colectivo Dynadia de Paris) }\end{array}$ & Partido Comunista de España \\
\hline \multirow[t]{2}{*}{1972} & Sega Cega (José Gandía Casimiro) & Situación del campo \\
\hline & \begin{tabular}{|l} 
Terres d'arròs (Joan Vergara Deltoro) \\
\end{tabular} & Situación del campo \\
\hline \multirow[t]{3}{*}{1974} & $\begin{array}{l}\text { Viaje a la explotación (Rosa Babi, Mercè } \\
\text { Conesa, Joan Simó, Bartomeu Vilà Sala, } \\
\text { Cooperativa de Cinema Alternatiu) }\end{array}$ & Inmigración \\
\hline & Caudillo (Basilio Martín Patino) & Francisco Franco \\
\hline & El sopar (Pere Portabella) & Presos políticos \\
\hline \multirow[t]{9}{*}{1975} & Camelamos naquerar (Miguel Alcobendas) & Minorías étnicas \\
\hline & $\begin{array}{l}\text { La ciudad es nuestra (Tino Calabuig y Miguel } \\
\text { Ángel Condor) }\end{array}$ & $\begin{array}{l}\text { Lucha de las asociaciones de vecinos } \\
\text { Problemas de urbanismo }\end{array}$ \\
\hline & $\begin{array}{l}\text { Un libro es un arma (Cooperativa de Cinema } \\
\text { Alternatiu) }\end{array}$ & Libertad de expresión \\
\hline & $\begin{array}{l}\text { Amnistía y libertad (Colectivo de Cine de } \\
\text { Madrid) }\end{array}$ & $\begin{array}{l}\text { Presos políticos. Lucha obrera. Lucha } \\
\text { estudiantil. Lucha de las asociaciones de } \\
\text { vecinos. Represión del Estado Franquista }\end{array}$ \\
\hline & \begin{tabular}{|l} 
Voces para unir, compartir, construir \\
(Colectivo de Cine de Madrid)
\end{tabular} & $\begin{array}{l}\text { Presos políticos. Reivindicación de las } \\
\text { nacionalidades. Lucha obrera }\end{array}$ \\
\hline & $\begin{array}{l}\text { Noticiari 1. Marxa de la llibertat (Cooperativa } \\
\text { de Cinema Alternatiu) }\end{array}$ & Reivindicación de los derechos nacionales \\
\hline & $\begin{array}{l}\text { Recital Raimon (Andrés Linares, Colectivo de } \\
\text { cine de Madrid) }\end{array}$ & Lucha por la democracia \\
\hline & $\begin{array}{l}\text { El campo para el hombre (Helena Lumbreras, } \\
\text { Mariano Lisa, Colectivo de Cine de Clase) }\end{array}$ & Situación del campo \\
\hline & $\begin{array}{l}\text { Carn Crua (Joan Martí i Valls, Cooperativa de } \\
\text { Cinema Alternatiu) }\end{array}$ & Guerra de Vietnam \\
\hline
\end{tabular}




\begin{tabular}{|c|c|c|}
\hline Año & Título & Tema \\
\hline \multirow[t]{14}{*}{1976} & $\begin{array}{l}\text { Hasta siempre en la libertad (Colectivo de } \\
\text { Cine de Madrid) }\end{array}$ & Lucha obrera. Pervivencias del franquismo \\
\hline & $\begin{array}{l}\text { Can Serra. La objeción de conciencia en } \\
\text { España (Cooperativa de Cinema Alternatiu) }\end{array}$ & Objeción de conciencia. Antimilitarismo \\
\hline & $\begin{array}{l}\text { Noticiari 2: La dona (Cooperativa de Cinema } \\
\text { Alternatiu) }\end{array}$ & $\begin{array}{l}\text { Luchas de las mujeres por sus derechos } \\
\text { sociales y políticos }\end{array}$ \\
\hline & $\begin{array}{l}\text { Noticiari 3: El Born (Cooperativa de Cinema } \\
\text { Alternatiu) }\end{array}$ & Reivindicaciones vecinales \\
\hline & \begin{tabular}{|l|} 
Vitoria, marzo 1976 (Colectivo de Cine de \\
Madrid)
\end{tabular} & Represión del Estado. Lucha obrera \\
\hline & Alborada (Lluís Garay y Joan Mallarach) & \begin{tabular}{|lcl} 
Represión del Estado Franquista. \\
Emigración. Lucha obrera
\end{tabular} \\
\hline & $\begin{array}{l}\text { Una fiesta por la democracia o el oro del P.C.E. } \\
\text { (Andrés Linares) }\end{array}$ & Partido Comunista de España \\
\hline & $\begin{array}{l}\text { O todos o ninguno (Helena Lumbreras, } \\
\text { Mariano Lisa, Colectivo de Cine de Clase) }\end{array}$ & Lucha obrera \\
\hline & $\begin{array}{l}\text { Primer aniversario de la muerte de Txiki } \\
\text { (Helena Lumbreras, Mariano Lisa, Colectivo } \\
\text { de Cine de Clase) }\end{array}$ & Represión del Estado Franquista \\
\hline & Del yugo y del canto (Joan Mallarach) & $\begin{array}{l}\text { Homenaje popular a Miguel Hernández. } \\
\text { Pervivencias del franquismo }\end{array}$ \\
\hline & Avui, abril 76 (Antoni Martí Gich) & $\begin{array}{l}\text { Prensa en catalán. Reivindicación cultural y } \\
\text { nacional catalana }\end{array}$ \\
\hline & Som una nació (Antoni Martí Gich) & Reivindicación de los derechos nacionales \\
\hline & $\begin{array}{l}\text { Informe general sobre algunas cuestiones } \\
\text { de interés para una proyección pública (Pere } \\
\text { Portabella) }\end{array}$ & Situación política \\
\hline & Gitanos sin romancero (Llorenç Soler) & Minorías étnicas \\
\hline \multirow[t]{7}{*}{1977} & Raza, el espíritu de Franco (Gonzalo Herralde) & Francisco Franco \\
\hline & Numax presenta... (Joaquim Jordà) & Lucha obrera \\
\hline & $\begin{array}{l}\text { A la vuelta del grito (Helena Lumbreras, } \\
\text { Mariano Lisa, Colectivo de Cine de Clase) }\end{array}$ & Lucha obrera \\
\hline & Independentzia! (Antoni Martí Gich) & Reivindicación de los derechos nacionales \\
\hline & Antisalmo (Llorenç Soler) & Iglesia y poder \\
\hline & Votad, votad, malditos (Llorenç Soler) & Consecuencias del franquismo \\
\hline & El proceso de Burgos (Imanol Uribe) & $\begin{array}{l}\text { Reivindicación de los derechos nacionales. } \\
\text { Lucha contra el franquismo }\end{array}$ \\
\hline
\end{tabular}

Los títulos que se citan se caracterizan por perseguir como objetivo informar de ciertas cuestiones que difícilmente aparecen en los medios de comunicación del momento, generar una toma de conciencia respecto a determinados problemas e incluso incitar a la acción política. Son películas que, obviamente, tratan temas conflictivos respecto 
a los estrechos márgenes de la libertad de expresión en la época. Ahora bien, dichos márgenes son cambiantes, y lo que puede considerarse reivindicativo en un momento, como sucede con D'un temps, d'un pais (1968) o Poetes catalans (1970), está plenamente aceptado pocos años más tarde, cuando las demandas ya persiguen fines distintos compárense ambas con Som una nació (1977)—. Otro ejemplo podemos encontrarlo en Canciones para después de una guerra, considerada muy ácida en su aproximación a la posguerra en 1971 — hasta el punto de ser prohibida — pero mucho más descafeinada en 1976, cuando pudo estrenarse (Nieto Ferrando, 2006: 89-95).

Las fechas que acotan este trabajo (1967-1977) responden a la aparición de 52 domingos (Llorenç Soler) y Numax presenta (Joaquim Jordà). La película de Soler es muy importante para la confluencia entre el cine independiente y el documental reivindicativo -es la primera que el director realiza fuera de las instituciones cinematográficas-. La película de Jordà, sin embargo, puede considerarse el final del ciclo, aunque sólo sea porque desde 1977, año de las primeras elecciones democráticas y de la desaparición paulatina de la censura, comienzan a poder abordarse los temas que tratan con mayor libertad y también a través de otros medios de comunicación. Con ello el cine contrainformativo y militante pierde su razón de ser y entra en lenta agonía. Esto no quita que podamos encontrar películas anteriores —Será tu tierra (Llorenç Soler, 1965), por ejemplo-y posteriores —Después de... (Cecilia Bartolomé y José Bartolomé, 1981), entre otras - muy significativas.

Las hipótesis de partida son las siguientes:

1. En el documental de los últimos años del franquismo y de la Transición parecen proliferar subnarradores de muy diverso tipo. Esto contrastaría con la uniformidad del narrador delegado en over del noticiario No-Do.

2. La relación entre la historia que narran estos subnarradores y los materiales audiovisuales aportados por el meganarrador se vuelve mucho más compleja. La imagen ya no sería redundante o ilustrativa respecto al relato en over, como sucede en el No-Do e incluso en los informativos de televisión, sino que pueden apreciarse un sinnúmero de situaciones que conducen a la complementariedad y a la contradicción.

3. Finalmente, y también como una manera de enfrentarse al No-Do, buena parte de los documentales reivindicativos del momento se caracterizarían por la reflexividad, por mostrar su propio carácter de construcción de un relato sobre la realidad y con ello buscarían romper con la transparencia. 


\section{EL NARRADOR EN EL CINE DOCUMENTAL}

Nuestro trabajo se sitúa en el ámbito del análisis del discurso, más en concreto de la narrativa audiovisual. Si bien en muchas ocasiones las cuestiones relacionadas con la narrativa han sido asociadas casi en exclusiva a la ficción audiovisual, estas están presentes en todos los trabajos que abordan la naturaleza del documental y su relación con la realidad y el espectador, aunque no hayan recurrido a los conceptos y términos propios de la narratología fílmica, tal como fueron heredados de los estudios literarios en la tradición académica francesa desde, como mínimo, Gerard Genette (1972) ${ }^{1}$. Es relativamente sencillo, por ejemplo, sustituir los términos autory actor social, tal como los emplea Nichols (1997), por narrador —o narrador delegado-y personaje, con todas las matizaciones que este último requiera respecto a la interpretación de los actores que los encarnan; incluso podemos apreciar su reconocida diferenciación entre documentales expositivos, observacionales, participativos y reflexivos como diferentes articulaciones de la historia — de los acontecimientos y los existentes- en el relato en función de un empleo particular de las variables narrador, focalización, tiempo o espacio.

Como resume Plantinga (1997: 104), "narrative itself is neither inherently fictional or nonfictional". Poco cambia en términos narratológicos, por tanto, si la narración se sostiene en la verosimilitud o en la veracidad: en un pacto con el espectador que, según determinadas estrategias, permite entender que los acontecimientos de la historia remiten a un mundo posible — que al mismo tiempo configuran-, como sucede en el cine de ficción, o hacen referencia a un mundo real, con entidad propia, que sería el caso del cine documental. De hecho, puede afirmarse que la veracidad es un efecto generado a partir de una articulación de los distintos componentes del relato que convencionalmente asume el espectador como propios de un discurso sobre la realidad.

En cualquier caso, resulta más sencillo apreciar las cualidades narrativas de los documentales cuando su historia está sustentada en acontecimientos más que en la descripción, la argumentación o la exposición de un tema. Estos últimos se estructuran en unidades - tampoco sería descabellado denominarlas secuencias- que tratan diversos aspectos de dicho tema desde diferentes ángulos hasta componer un mapa del mismo: las minorías étnicas en Camelamos naquerar, los barrios periféricos de las grandes ciudades y la inmigración en Un lloc per dormir, la situación del campo en Terres d'arròs o El campo para el hombre, dentro de las películas que nos ocupan. En los primeros, sin embargo, la narración viene pautada por los propios acontecimientos, que tienen una temporalidad, la de la historia, aunque su orden en el relato —aquí sin duda muy importante- pueda diferir de esta en función del efecto buscado por el meganarrador.

1 Entre los trabajos que han tratado el documental desde una perspectiva narratológica destacan los de Jost (1989), Guynn (1990), Colleyn (1993), Gaudreault y Marion (1994) o Vallejo (2008). 
Sería el caso de $O$ todos o ninguno y Numax presenta, que narran las huelgas de las empresas Laforsa o Numax.

Los documentales cuya historia está basada en acontecimientos están más cerca de la configuración narrativa de la ficción. En O todos o ninguno y Numax presenta las huelgas, además, son conflictos claramente delimitados - y el conflicto es la base del dramaentre propietarios y obreros. Incluso emplean un patrón argumental compartido con la ficción que, tal como indica Monterde (1997: 31), requiere de una serie de episodios recurrentes: "La asamblea, la ocupación de las fábricas o de las tierras, la manifestación en las calles, la represión policial o militar, la aparición de esquiroles o rompe-huelgas, las negociaciones, las penurias de las familias huelguistas, las represalias, el dulce momento del éxito o el amargo retorno al tajo, etc.". No obstante, lo frecuente es que la articulación a través de acontecimientos y temas confluya. Dentro del corpus de películas analizado destacan en este sentido Mitin en Montreuil y El sopar, donde los acontecimientos —un mitin y una cena - son apenas envoltorios para proponer una película temática sobre las perspectivas del Partido Comunista de España respecto a la previsible llegada de la democracia con la muerte de Franco o la situación de los presos políticos de la dictadura. También es habitual que en los documentales temáticos algunos subnarradores narren acontecimientos.

Cuando centramos nuestra atención en el narrador, apreciamos con facilidad cómo las categorías elaboradas para la ficción audiovisual son igualmente aplicables al documental. De entrada debemos distinguir entre meganarrador o "gran imaginador" (Gaudreault y Jost, 1995: 51) y los subnarradores o narradores delegados. El primero es responsable de todo el proceso narrativo, de la conjugación de los elementos icónicos, verbales y musicales, así como de las dos capas de narratividad: la mostración concretada en la puesta en cuadro y la puesta en escena - y la narración —formulada a través del montaje- (Gaudreault y Jost, 1995: 63-64). Los segundos, los subnarradores son entidades que en algún momento ejercen la función de narradores, ya sean o no personajes de la historia. Casetti prefiere diferenciar entre enunciador, instancia abstracta responsable de la enunciación o, en otras palabras, del "apropiarse y el apoderarse de las posibilidades expresivas ofrecidas por el cine para dar cuerpo y consistencia al film", de los narradores: "Figurativizaciones de las instancias abstractas sobre la superficie del texto" $(1989: 42,67)$.

La "tendencia casi 'natural' a la delegación narrativa" en el cine (Gaudreault y Jost, 1995: 57) adquiere en el documental una nueva dimensión, sobre todo en comparación con la ficción. En el caso del corpus analizado, además, es apreciable la diversidad de subnarradores diegéticos y extradiegéticos, sin que nada impida que los primeros - ya sean autodiegéticos u homodiegéticos- puedan ejercer en determinados momentos de los segundos. A ello hay que añadir, con independencia de si pertenecen o no a la diégesis, 
su disparidad de grado de conocimiento de la historia — si son omniscientes o saben más, lo mismo o menos que los personajes - e implicación, ya sea como subnarradores neutros, valorativos —exponen juicios de valor-, selectivos — filtran la historia en función de sus características particulares - o multiselectivos, en el caso este último de que varios narradores diegéticos o extradiegéticos narren acontecimientos diferentes desde su punto de vista —narradores monoscópicos — o el mismo acontecimiento narradores poliscópicos- (García Jiménez, 1996: 106-123).

Si bien el meganarrador sigue teniendo autoridad absoluta en las películas analizadas —es el responsable último de todo el proceso_-, su presencia delegada ya no se reduce a la del narrador extradiegético en over omnipresente propia de la modalidad expositiva de documental (Nichols, 1997: 68-72), en la que podemos situar los noticiarios. Obsérvese que en el No-Do la historia narrada por el narrador en over predomina sobre la imagen, ya sea concretando su sentido — cuando no confiriéndoselo- o redundando con ella. Por regla general desaparece el sonido natural de la imagen; incluso las declaraciones de algunos personajes son citadas en estilo indirecto por el subnarrador (Tranche y SánchezBiosca, 2001: 118-125). Los vítores, aplausos y otros sonidos que parecen emanar de la propia imagen son en muchas ocasiones añadidos mediante el montaje. A ello hay que añadir la uniformidad del tono de su discurso, con independencia de la noticia, y la tendencia, apreciable sobre todo en sus primeros lustros, a "la artificiosidad, a emplear un tono rimbombante y ampuloso absolutamente huero [...]. Es más, la impronta de la retórica falangista con su predilección por los epítetos floridos y altisonantes subyace en él", así como la presencia de expresiones "que pertenecen al acervo del Régimen [...]: 'pertinaz sequía', 'trascendental discurso', 'muestras de adhesión inquebrantable', 'admirable disciplina', 'impecable formación', 'invicto Caudillo', 'guerra de liberación', 'barbarie marxista,' 'yugo soviético'...' (Tranche y Sánchez-Biosca, 2001: 120).

\section{NARRADORES DELEGADOS Y ESPACIO EN OVER}

El papel del narrador extradiegético en over cambia de manera importante en las películas analizadas, tanto si mantiene su estatuto de principal conductor de la historia como si debe compartirlo con otros narradores. El narrador en over predomina en Montserrat, assemblea d'intel.lectuals (Muntanya) y en El Born, tercera entrega del noticiario producido por la Cooperativa de Cinema Alternatiu. Obsérvese que la primera es una película marcadamente contrainformativa, dado que busca dejar testimonio de un acontecimiento susceptible de ser omitido o tergiversado por la prensa: el encierro en la Abadía de Monserrat en protesta por el denominado Proceso de Burgos. La segunda sigue los cánones, aunque actualizados, del noticiario, pero rompe con la tónica de las dos entregas anteriores -Marxa de la llibertat y La dona-, donde son frecuentes los 
personajes ejerciendo de narradores. En cualquier caso, en ambas películas el tono del discurso del narrador en over está muy alejado del empleado en el No-Do.

El narrador en over también puede estar ausente -Aidez l'Espagne y Carn Crua-, ser sustituido por un galimatías indescifrable —el idioma inventado en Distància, de 0 a infinit-, la música - Canciones para después de una guerra y Voces para unir, compartir, construir- o intertítulos, como sucede en A la vuelta del grito. Lo más frecuente, sin embargo, es que no desaparezca, aunque pierda su omnipresencia ya sea por mostrar el meganarrador mayor confianza en la capacidad narrativa de las propias imágenes -en un momento concreto de Largo viaje hacia la ira, por ejemplo, la voz en over solo dice "La noche", sin redundar en el sentido de las imágenes, que permiten mostrar las condiciones de hacinamiento en las que duermen los inmigrantes recién llegados a Barcelona- o compartir su papel con los personajes. Así sucede en buena parte de las películas. En D'un temps, d'un pais, el narrador en over narra ciertos episodios de la biografía de Raimon o sobre su Xàtiva natal, pero junto al propio cantante, que también ejerce de narrador autodiegético. En La ciudad es nuestra la voz en over ajena a la historia aporta determinadas especificaciones y datos demográficos, pero son los protagonistas de las asociaciones vecinales quienes ejercen de conductores de la historia. En ambos casos el narrador extradiegético en over se limita a completar o contextualizar con mayor o menor grado de intervención lo que narran los personajes.

Los relatos de esta última película y $O$ todos o ninguno y Numax presenta, en gran medida debido a sus condiciones de producción -compartida entre los realizadores y los propios protagonistas de sus historias-, generan el efecto de pérdida de autoridad del meganarrador, al quedar esta diluida, en apariencia, en la negociación con los personajes. En las tres se indica la autoría colectiva, ya sea mediante un rótulo, un intertítulo o las propias declaraciones de los directores y los personajes. En La ciudad es nuestra el destacado papel de los personajes es apreciable en los testimonios de los representantes de asociaciones vecinales, cuya excesiva presencia entorpece la fluidez narrativa en favor de sus análisis de los problemas de urbanismo y su relación con la inmigración. Los testimonios son ilustrados con planos de los barrios periféricos de Madrid, en ocasiones contrastados mediante insertos con los barrios más acomodados. O todos o ninguno cuenta incluso con material rodado por los propios trabajadores, lo que incide en el efecto de realidad: el filtro entre los hechos y el espectador, al menos en su registro, no es un director o un meganarrador que pudiera ser ajeno a los mismos, sino uno de los personajes, en este caso trabajadores, que los protagoniza. Finalmente, en Numax presenta los propios protagonistas producen y narran su historia e incluso en determinados momentos la reconstruyen o la dramatizan.

En cualquier caso, los personajes de la diégesis que actúan como narradores autodiegéticos u homodiegéticos, ya sea mediante monólogos, monólogos alternados, 
diálogos con otros personajes o con un entrevistador - cuya presencia puede ser explícita o sugerida-, no pueden reducirse a su función en el documental expositivo, a ilustrar o corroborar lo que determina una voz extradiegética. Sus aportaciones, además, pueden convertirse en over ocasionalmente. Sucede con Tierno Galván en Spagna 68, entrevistado en un plano cuyo relato sobre la situación de la universidad se transforma en over en los siguientes. Los ejemplos de esto último son numerosos en los documentales analizados.

En otras ocasiones encontramos narradores que ocupan un estatuto difícil de situar dentro o fuera de la diégesis. Son personajes que solo actúan en el espacio en over. Sería el caso de la sucesión de testimonios que analizan la situación de los estudiantes y sus aspiraciones en Spagna 68, sin que pueda apreciarse visualmente su fuente. Puede inferirse, en todo caso, que son los propios estudiantes, dado que protagonizan numerosos planos. Hasta siempre en la libertad emplea un recurso similar. En cierto momento la cámara recorre el despacho laboralista lleno de clientes, mientras que en over se suceden mediante breves fragmentos de monólogos alternados las narraciones de las distintas vicisitudes que les han conducido hasta allí, sin que de nuevo sea posible identificar a los emisores de las narraciones. De la misma manera sucede en 52 domingos, donde los primerísimos primeros planos de los aspirantes a toreos permiten apreciar que lo que el espectador escucha es lo que ellos narran, aunque de nuevo no aparezca con claridad la fuente.

Estos personajes narradores en over son selectivos dado que filtran los acontecimientos en función de sus particularidades. Los encontramos también en Largo viaje hacia la ira, Alborada o No se admite personal. En estas películas, sin embargo, la distancia entre su narración y la imagen es mucho más amplia: personalizan la historia sin que los planos que la acompañan permitan asociarla de ninguna manera a un personaje o personajes, además de convertirla en ejemplar, en una sinécdoque que remite a situaciones más generales. En el caso de Largoviaje hacia la ira la narración del personaje vieneacompañada de imágenes de anuncios publicitarios, terrazas de cafeterías, edificios en barrios acomodados y personas caminando por la calle. En Alborada el personaje en over narra su propia historia, la de un trabajador-tipo, hijo de perdedores de la guerra, represaliado, que pasó hambre en Granada, tuvo que malvivir como emigrante en Barcelona, participó en las primeras huelgas de los años cincuenta, después volvió a emigrar a Alemania y regresó para embarcarse en las luchas por los derechos de los trabajadores. De nuevo es imposible asociar su relato visualmente a un personaje individual o colectivo concretos. En fin, No se admite personal invierte el proceso: el trabajador-tipo protagoniza la imagen —el relato visual sigue las peripecias de un trabajador en busca de empleo- mientras que el espacio en over está poblado de personajes ejerciendo de narradores a través de un discurso construido mediante diálogos y monólogos alternados. 
La relación entre el relato de los narradores en overy la imagen también se diversifica. Si bien en muchas ocasiones la imagen todavía es redundante e ilustrativa, en otras produce singulares comparaciones y contradicciones. Así puede apreciarse en Sega Cega, donde los planos del cultivo del arroz en Valencia y de las fiestas asociadas a su gastronomía, vienen acompañados de unas omnipresentes voces en over que hacen referencia tanto a la situación del campo y sus trabajadores como a la naturaleza del cine y su capacidad para representar la realidad. En la película de Gandía la imagen en ocasiones ilustra el relato del narrador y en otras permite insospechadas comparaciones que conducen al extrañamiento. La contradicción la encontramos en la primera intervención de la voz en over extradiegética en La ciudad es nuestra, que narra la situación de los barrios periféricos marginales de Madrid al mismo tiempo que es ilustrada por vistas turísticas de la capital —-por tanto, completamente ajenas a la historia narrada—. De igual manera, en Camelamos naquerar los decretos y disposiciones contra los gitanos, reproducidos en over, contrastan con los planos de su vida humilde e inofensiva, en chabolas o cuevas.

Caudillo es sin duda una de las películas más prolijas en las contradicciones entre la voz en over y la imagen -Basilio Martín Patino, su director, ya las había ensayado con la música en Canciones para después de una guerra-. El narrador, apropiándose de la retórica más exaltada de la dictadura, justifica el alzamiento militar como la reacción de una España que otra vez, "desde hace mil años, levanta la espada en defensa de los valores espirituales y de la ortodoxia religiosa... Siempre en nombre de Dios", vinculándolo a las cruzadas y a la denominada Reconquista. Las imágenes desmienten la ortodoxia religiosa al mostrar las tropas marroquíes, probablemente musulmanas, que contribuyeron al triunfo de los sublevados. En otro momento empuja al espectador a comparar "la más alta legitimidad de Franco" como líder, tal como indica, con su estatura física, apreciable en un plano que comparte con Charles de Gaulle.

Obsérvese que el espacio en over está plagado de citas -informes, edictos, poemas, etcétera-, señalando o no la fuente, en estilo directo, indirecto o indirecto libre. En ocasiones son documentos sonoros, como las conversaciones entre los policías por radio en el comienzo Vitoria, marzo 1976, acompañados de planos que muestran los efectos de la represión, o los discursos de Franco en El altoparlante, aquí, de nuevo, en contraposición con los primeros planos y planos medios de ciudadanos anónimos, de lo que se infiere la distancia entre estos discursos y las clases populares. También abundan las parodias del discurso ampuloso del No-Do y en general de las expresiones propias de la retórica franquista, aunque no estén ligadas a un texto concreto, contrastadas con la imagen y con ello generando un efecto irónico. Esto llega a la exasperación con el galimatías indescifrable con el que arranca Distància, de 0 a infinit, de nuevo con el NoDo en el punto de mira, ilustrado con planos de monumentos y edificios turísticos de Barcelona. Las citas en otras ocasiones incluyen una valoración explícita del narrador el 
over. En Terres d'arros, por ejemplo, reproduce buena parte de los tópicos que glorifican la armonía del mundo rural, valorándolos negativamente. Esta película, además, reproduce parte del "Canto a la paella" de José María Pemán, autor que es presentado con cierta sorna como el máximo exponente de la relación entre la paella y la política.

También puede apreciarse en el corpus analizado la gran diversidad de tonos en los discursos de los narradores en over, que van desde la ampulosidad paródica hasta el poético. Pero destaca sobre todo el uso en ocasiones un estilo aséptico y la utilización de un léxico propio del científico social -los datos demográficos y geográficos de Monegros - , donde cada palabra intenta ajustarse a un sentido univoco. El narrador en over también interpela directamente al espectador: “¿Hasta cuándo?", pregunta después de describir todos los problemas de los inmigrantes recién llegados a la gran ciudad en Largo viaje hacia la ira.

En el espacio extradiegético destaca igualmente la música, en ocasiones atonal y disonante, que pasa por buena parte de las funciones atribuidas a la misma en el relato: anticipadora de acontecimientos, referencial, identificadora de determinados personajes -la asociación entre flamenco y clase populares e inmigrantes en muchas películas-, lubrificadora de las fracturas del discurso, etcétera (García Jiménez, 1996: 262-271). En algunas películas las canciones y las letras que les acompañan pueden tener un papel narrativo de primer orden, llegando, como sucede en Voces para unir, compartir, construir, a suplantar al narrador en over y a reducir la imagen casi a ilustración de la letra de las canciones. En El campo para el hombre, el papel narrativo de la letra de las canciones permite un sumario, una condensación en poco tiempo del relato de un amplio tiempo de la historia, en concreto de la historia del campesinado gallego desde la Edad Media hasta el final del franquismo. En fin, en Canciones para después de una guerra, la relación entre la música y la imagen es disonante y contradictora, lo que empuja hacia el efecto irónico.

\section{IRONÍA, SINÉCDOQUE Y REFLEXIVIDAD}

Es indudable que la ironía, parodiando en muchas ocasiones el estilo de otros discursos, plantea la actitud del narrador respecto a lo narrado — de hecho siempre contiene un juicio de valor sobre lo narrado-, requiere de la colaboración del espectador inscrito en una comunidad interpretativa capacitada para inferir el sentido connotado de la literalidad y conduce el documental hacia la reflexividad. Ahora bien, como puede apreciarse en Caudillo, en muchas ocasiones es posible inferir la ironía de la contradicción entre el relato de un narrador en over y los materiales visuales que aporta 
el meganarrador, responsable último de la articulación de todos los elementos del relato; si no es así, dicha contraposición desacredita al narrador en over².

El narrador también puede ser irónico. En El campo para el hombre la parodia de los cánones del cuento infantil permiten al narrador en over ironizar sobre las excelencias de la España franquista extractando algunos de sus tópicos propagandísticos, y al mismo tiempo sugerir la condición infantilizada y crédula que estos asignaban al destinatario. En este caso no hay una contradicción entre la historia que narra y los planos que la acompañan, más bien complementariedad y redundancia. La ironía puede igualmente inferirse de la actividad del meganarrador, en concreto de la puesta en serie y de la contradicción, más que entre la vozen overy la imagen, entre los distintos acontecimientos presentados en sucesión. En Noticiario RNA, sin embargo, el efecto irónico se sustenta en la parodia y la hipérbole de los elementos constitutivos del No-Do: las unidades narrativas compuestas en buena parte por noticias blandas, no atadas temporalmente a la realidad inmediata - la educación sexual de las alumnas de un colegio-, el tratamiento de acontecimientos previsibles - la visita del ministro de Avances Industriales, donde el narrador en over deja paso al discurso del propio personaje, seguido de una ovación, recurso este último frecuente que evidencia el carácter propagandístico del noticiario-, algunos serios y otros frívolos, el interés por las innovaciones técnicas, las curiosidades y lo insólito heredado de las atracciones —el cráneo/cámara de origen alienígena encontrado en unas excavaciones-, todo ello ligado por un narrador en over que concreta el sentido de la imagen, aunque en ocasiones está le contradiga — la visita del ministro de Avances Industriales ilustrada con planos de escombros-.

La parodia de Noticiario RNA parte de un género, el del noticiario, ampliamente utilizado con fines propagandísticos. Los hipotextos de Caudillo y Raza, el espíritu de Franco son películas concretas: Franco, ese hombre (José Luis Sáenz de Heredia, 1964) y Raza (José Luis Sáenz de Heredia, 1941). La presencia de Franco, ese hombre en la película de Patino puede apreciarse en un sinnúmero de alusiones que acaban por rebatir, incluso deconstruir, la imagen del dictador elaborada en este biopic documental. En Raza, el espíritu de Franco, el hipotexto es evidente, y permite a los personajes — Pilar Franco, hermana de Franco, y Alfredo Mayo, actor que interpreta al héroe de Raza - contrastar los diversos pasajes de la vida del dictador con la biografía que hubiera deseado tener; no en vano, fue el propio Franco el guionista de la película de Sáenz de Heredia (Gubern, 1977).

La ironía y la parodia no son los únicos recursos que utiliza el documental del momento: también nos encontramos con símiles y sinécdoques. Los símiles se articulan muchas veces a través de insertos extradiegéticos como los de Aidez l'Espagne, que

2 Sobre la ironía y la voz en over véase Kozloff (1988: 102-126). 
comparan a los militares sublevados en 1936 con algunas figuras de grabados de Joan Miró, o los de Urani 235, que hacen lo mismo con imágenes de la guerra de Vietnam y el Guernica. No obstante, los insertos no son empleados exclusivamente para establecer comparaciones. En ocasiones, como sucede con los planos de carteles publicitarios en Largo viaje hacia la ira, contrapuntan la historia que narran los personajes. En Can Serra, los insertos — planos de tanques, de niños con armas y heridos - son anticipaciones del giro que dará una historia que arranca con la descripción del barrio Can Serra, en Hospitalet de Llobregat, para más adelante introducirse en el problema de la objeción de conciencia y el pacifismo.

Los narradores extradiegéticos también recurren a la sinécdoque con la intención de trascender de lo particular a lo más general. Sucede, ya lo hemos visto, con los personajes en over de 52 domingos, Largo viaje hacia la ira o Alborada, dado que su caso particular puede considerarse una concreción de situaciones generales que viven los aspirantes a toreros, los inmigrantes y los trabajadores. Pero en ocasiones esos casos concretos son planteados como efectos de una causa más amplía. Así sucede con los intertítulos de A la vuelta del grito, donde se sugiere que la difícil situación que viven los trabajadores es consecuencia de las propias contradicciones del sistema capitalista y de sus crisis cíclicas, y ante ello solo hay una solución: el socialismo. De igual manera, la inmigración es un epifenómeno de la sociedad capitalista y su voluntad de tener bajo control las reivindicaciones obreras - Viaje a la explotación -, incluso de la propia situación generada por el franquismo. En Un lloc per dormir, por ejemplo, la causa de la pobreza y la miseria en los barrios periféricos se aprecia en el epílogo de la película: la imagen de Franco en una pantalla de televisión. Obsérvese que aquí la sinécdoque ya no surge del discurso de los narradores delegados, sino de la articulación del relato por parte del meganarrador. De igual manera sucede en Carn crua, ya que el montaje paralelo de planos de la guerra de Vietnam y planos de obreros en fábricas permite inferir que estamos ante dos efectos de una causa común: las relaciones sociales de producción capitalistas.

Algunas tradiciones críticas y analíticas que confían en la capacidad del arte para generar alguna forma de conocimiento sobre la sociedad —el realismo de cariz marxista, por ejemplo- se sustentan en la posibilidad de que los acontecimientos y personajes singulares representados trasciendan su singularidad. Tal como resume Darío Villanueva (2004: 56), el "detalle, precisamente en cuanto — por acertada elección del artistaresulte típico, permitirá ese salto trascendente a lo esencial considerado imprescindible por Lukács y los teóricos marxistas del realismo. La obra de arte siempre dará, por fuerza, una sección o fragmento de la realidad, pero su propósito último ha de ser que dicha sección no aparezca desgajada de la totalidad de la vida social". Linares (1976) considera que esta es una de las características definitorias del arte militante: el abordar problemas concretos de tipo social, que afectan a la vida diaria, pero extrayendo a partir de estos 
conclusiones generales. Muchas de las películas analizadas, además, no se limitan la exposición de un problema ejemplar, sino que los propios narradores o el desarrollo de los acontecimientos en la historia plantean sus soluciones: la sustitución del servicio militar por los trabajos para la comunidad en Can Serra, la unión, el cooperativismo y la conciencia de clase en El campo para el hombre o el socialismo en A la vuelta del grito. Con todo, El cuarto poder llega a la exhortación directa para que el espectador actúe fuera de la historia que le es narrada: "Crea tu prensa. Divulga tu prensa”, se indica en un intertítulo después de la narración de las manipulaciones de la prensa bajo el franquismo.

En cualquier caso, en las películas analizadas parece más apropiado buscar un referente teórico en las propuestas de Brecht, que además de separar el realismo de unas formas específicas, teoriza sobre el efecto de distanciamiento, la necesidad de extraer al espectador de la ilusión diegética creada mediante la convención naturalizada (Brecht, 1970); en nuestro caso, la ilusión de acceso al mundo real o de una narración unívoca sobre el mundo real. Obsérvese, además, que algunas de las concepciones de la ironía, como la denominada "ironía romántica", se sustentan justamente en la reflexividad, en la ruptura de la ilusión y en el distanciamiento crítico (Schoentjes, 2003: 87-113).

Entre las características recurrentes de una parte importante de los documentales políticos y sociales analizados destaca la búsqueda del extrañamiento y la exhibición de las marcas que denotan la condición de construcción y artificio del documental. Uno de los recursos más frecuentes es la presencia del dispositivo de registro y de reproducción de la imagen: el objetivo con el que arranca Distància, de 0 a infinit, la presencia cámaras y otros aparatos en buena parte de los planos de Monegros, su evidencia a partir de la imagen desenfocada en los planos generales de Poetes catalans, los proyectores en Un lloc per dormir o las pantallas en Cega sega. En películas como esta última son también los narradores quienes rompen con la ilusión al reflexionar continuamente sobre la relación entre el cine y la realidad. Monegros, que concluye con una afirmación taxativa por parte de un narrador en over, "El cine no es la realidad", emplea las yuxtaposiciones inesperadas a través de insertos, los bocadillos de cómics e incluso las representaciones.

Finalmente, el efecto de extrañamiento puede proceder de la introducción de la ficción en el documental, de nuevo una manera de enfrentarse a la veracidad asociada a este tipo de cine y, más en concreto, al No-Do. A la vuelta del grito recurre a la dramatización de situaciones en las que los personajes dialogan sobre las consecuencias del cierre de fábricas. En ocasiones las dramatizaciones van más allá de la mera reconstrucción. Así sucede en Numax presenta, donde las representaciones teatrales contextualizan el conflicto en la fábrica, y con ello asumen una de las nuevas funciones asignadas del narrador en over en el documental de la Transición con una actitud valorativa al recurrir a la sátira. La película de Jordà contiene también reconstrucciones de diálogos y acciones protagonizadas por los propios personajes, estimulando el efecto participativo y, con 
ello, de un control de la historia compartido entre el meganarrador y los personajes ya no sólo entre narradores en over y personajes-. De igual manera, la presencia del actor Francesc Lucchetti en diferentes situaciones e interpretando distintos papeles en Informe general -entre manifestantes, paseando por las diferentes estancias del palacio de El Pardo, como técnico de filmoteca, etcétera-, incluso ejerciendo de narrador, contribuye a la ruptura con la ilusión de transparencia. A ello se añaden en la película de Portabella otros recursos, entre los que destacan las reconstrucciones o la mostración de la organización de la puesta en escena en las entrevistas.

\section{CONCLUSIONES}

Como se ha señalado en estas páginas, el enfrentamiento al No-Do y a otros textos propagandísticos e informativos de la dictadura en los documentales analizados va mucho más allá del tratamiento de temas proscritos.

Dicho enfrentamiento es especialmente apreciable en la proliferación de narradores, tanto extradiegéticos como diegéticos, y en la actitud de estos respecto a lo narrado, que contrastan con claridad con la uniformidad y presencia absoluta de una única voz en over en el noticiario. La uniformidad es rota con la aparición de diferentes narradores en over - frente al único que regía el No-Do-, con discursos que pueden recurrir tanto al tono y al léxico del científico social como, entre muchas otras situaciones, a la parodia de los lugares comunes de la propaganda franquista. Su presencia absoluta se diluye al asumir los personajes funciones narrativas. En este sentido destacan los personajes que solo actúan como narradores autodiegéticos y homodiegéticos en over, concretando en su propia experiencia los comentarios del narrador extradiegético.

El espacio en over, además, se dota de enorme complejidad: músicas, citas en estilo directo o indirecto, documentos sonoros, etcétera. Y lo mismo sucede con su relación con la banda de imagen. La redundancia o ejemplaridad del documental expositivo es sustituida, como mínimo, por la complementariedad y la contradicción. De ello surge en muchas ocasiones un efecto irónico, que junto al empleo de símiles o parodias conducen al documental a la reflexividad. Una parte importante del corpus de películas analizado, además, recurre a toda suerte de recursos que provocan extrañamiento y distanciamiento, que muestran su condición de construcción de un discurso sobre la realidad, de nuevo enfrentándose al relato unívoco sobre la realidad del documental expositivo.

Obsérvese, por otra parte, que las ironías, los símiles, las sinécdoques, las parodias, etcétera, son recursos que puede apreciarse ya en el cine de ficción bajo el franquismo de los años cincuenta, con un menor quebranto de la ilusión diegética, y todavía en la primera mitad de los setenta alimentan lo que se dio en llamar cine metafórico. Su objetivo principal es ejercitar una disidencia posibilista —es decir, dentro del sistema 
cinematográfico-, y con ello intentar sortear los problemas que el tratamiento directo de ciertos temas hubiera generado con la censura. El documental político del momento, sin embargo, rompe con el posibilismo, apuesta por abordar sus temas sin trabas, aunque ello le excluya de los canales pautados por las instituciones cinematográficas del franquismo y la Transición. El objetivo principal del empleo de estos recursos es ahora la persuasión, más que la elusión, en estrecha relación con la función atribuida a este tipo de cine.

Si bien nos hemos centrado aquí sobre todo en el análisis de los narradores y la reflexividad, surgen algunas cuestiones que van más allá de las planteadas que podrían completar nuestra aproximación. En primer lugar, el estudio del narratario y del enunciatario, igualmente complejos en el corpus de películas abordado y difíciles de desligar del objetivo que persiguen: informar de aquellos temas ausentes en los medios de comunicación del momento, despertar la toma de conciencia respecto a ciertos problemas sociales e incluso estimular la acción política. En segundo lugar, hemos apuntado un concepto, el de espacio en over, que requeriría de una mayor teorización. Es un espacio distinto a los que permiten componer la diégesis: el espacio representado y el espacio no mostrado - en fuera de campo-, aunque continuamente sugerido y susceptible de ser representado mediante montaje en una secuencia temporal. Es un espacio extradiegético y sonoro que puede dotarse, como ha podido apreciarse, de una gran diversidad.

Podemos añadir dos cuestiones más de carácter general. Por una parte, es necesario establecer una categorización clara — sin que por ello deje de ser flexible- que diferencie entre documental político, social, contrainformativo, militante o de agitación y propaganda. Estas distinciones se dan habitualmente por sabidas o no son abordadas con suficiente rigor. Aquí hemos evitado entrar en el problema, dado que la ubicación justificada de las películas analizadas en cada una de ellas hubiera dado lugar a un artículo distinto. Es indudable, en cualquier caso, que cada tipo de documental persigue unos objetivos distintos y pone un énfasis diferente en algunos de sus elementos constitutivos. En segundo lugar, es muy difícil entender el desarrollo del cine documental político del momento sin atender a la abundante reflexión crítica, analítica y teórica que le acompaña, muchas veces elaborada por los propios directores, que justamente intenta establecer categorías, definir su función política y social, su lugar respecto a las instituciones cinematográficas o su relación con la realidad. También plantea si la denuncia, la contrainformación o la voluntad de intervención deben venir acompañadas de la puesta en cuestión de los modelos de representación reconocibles por el público o recurrir a estos debido a su mayor efectividad. A través de estas reflexiones puede apreciarse cómo los directores, críticos y analistas son conscientes de estar enfrentándose con sus prácticas fílmicas a los discursos audiovisuales informativos y propagandísticos de la dictadura, y en concreto al No-Do. 


\section{REFERENCIAS BIBLIOGRÁFICAS}

ANTOLÍN, M. (1979). Cine marginal en España. Valladolid: Semana Internacional del Cine de Valladolid.

ARNAU ROSELLÓ, R. (2006). La guerrilla de celuloide. Castellón de la Plana: Universitat Jaume I. BERZOSA, A. (2009). Cámara en mano contra el franquismo. Buenos Aires: Ediciones al Margen. BRECHT, B. (1970). Escritos sobre teatro. Buenos Aires: Nueva Visión.

CASETTI, F. (1989). El film y su espectador. Madrid: Cátedra.

CATALÀ, J. M.; CERDÁN, J. y TORREIRO, C. (eds.) (2001). Imagen, memoria y fascinación. Notas sobre el documental en España. Madrid/Málaga: Ocho y medio/Festival.

COLLEYN, J. P. (1993). Le regard documentaire. París: Editions du centre Pompidou.

EXPÓSITO, M. (ed.) (2001). Historias sin argumento. El cine de Pere Portabella. Valencia/ Barcelona: Ediciones de la Mirada/Museu d'Art Contemporani de Barcelona.

FANÉS, F. (2008). Pere Portabella. Avantguarda, cinema, política. Barcelona: Institut Català de les Indústries Culturals/Pòrtic.

FRANCÉS, M. (ed.) (2012). La mirada comprometida. Llorenç Soler. Madrid: Biblioteca Nueva.

GARCÍA JIMÉNEZ, J. (1996). Narrativa audiovisual. Madrid: Cátedra.

GARCÍA-MERÁS, L. (2007). “El cine de la disidencia. La producción militante antifranquista (1967-1981)". Desacuerdos 4, 16-41.

GAUDREAULT, A. y JOST, F. (1995). El relato cinematográfico. Cine y narratología. Barcelona: Paidós.

GAUDREAULT, A. y MARION, Ph. (1994). "Dieu est l'auteur des documentaires". Cinémas: revue d'études cinématographiques/Cinémas: Journal of Film Studies 4-2, 11-26.

GENETTE, G. (1972). Figures III. Paris: Éditions du Seuil.

GUBERN, R. (1977). Raza, un ensueño del general Franco. Barcelona: Ediciones 99.

GUYNN, W. (1990). A Cinema of nonfiction. Rutherford/ Londres: Fairleigh Dickinson University Press/Associated University Presses.

HERNÁNDEZ, J. y PÉREZ, P. (1998). Yo filmo que... Antonio Artero en las cenizas de la representación. Zaragoza: Ayuntamiento de Zaragoza.

JOST, F. (1989). “Documentary: Narratological approaches”. En Image, Reality, Spectator, Willem De Greef, y Willem Hesling (eds.), 77-90. Lovaina: Acco.

KOZLOFF, S. (1988). Invisible Storytellers. Voice-Over Narration in American Fiction Film. Berkeley: University of California Press.

LINARES, A. (1976). El cine militante. Madrid: Castellote.

MARTí ROM, J. L. (1978). "Breve historia acerca del cine marginal (cines independiente, underground, militante, alternativo) en el contexto catalán". Cinema 2002 38, 56-60.

MEDINA, P.; GONZÁLEZ, L. M. y VELÁZQUEZ, J. M. (eds.) (1996). Historia del cortometraje español. Alcalá de Henares: Festival de Cine de Alcalá de Henares. 


\section{JORGE NIETO FERRANDO}

MONTERDE, J. E. (1997). La imagen negada. Representaciones de la clase trabajadora en el cine. Valencia: Filmoteca de la Generalitat Valenciana.

NICHOLS, B. (1997). La representación de la realidad. Cuestiones y conceptos sobre el documental. Barcelona: Paidós.

NIETO FERRANDO, J. (2006). Posibilismos, memorias y fraudes. El cine de Basilio Martín Patino. Valencia: Ediciones de la Filmoteca.

PLANTINGA, C. R. (1997). Rhetoric and representation in nonfiction film. Cambridge: Cambrige University Press.

ROMAGUERA I., RAMIÓ, J. y SOLER, L. (2006). Historia crítica y documentada del cine independiente en España, 1955-1975. Barcelona: Laertes.

SCHOENTJES, P. (2003). Poética de la ironía. Madrid: Cátedra.

TRANCHE, R. R. y SÁNCHEZ-BIOSCA, V. (2001). NO-DO. El tiempo y la memoria. Madrid: Cátedra/ Filmoteca Española.

VALLEJO, A. (2008). "Protagonistas de lo real. La construcción de personajes en el cine documental". Secuencias 27, 72-89.

VILLANUEVA, D. (2004). Teorías del realismo literario. Madrid: Biblioteca Nueva.

VIOTA, P. (1982). El cine militante en España durante el franquismo. México: Filmoteca de la Universidad Nacional Autónoma de México.

VV.AA. (1977). “Cine militante". El viejo topo 7, 55-59.

Recibido el 26 de enero de 2016.

Aceptado el 1 de noviembre de 2016. 